\title{
Antitumor Effects of Eribulin Mesylate in Gemcitabine-resistant Pancreatic Cancer Cell Lines
}

\author{
YUKA TAKEZAKI ${ }^{1}$, TSUTOMU NAMIKAWA ${ }^{1}$, TSUYOSHI KOYAMA ${ }^{2}$, ERI MUNEKAGE ${ }^{1}$, \\ MASAYA MUNEKAGE ${ }^{1}$, HIROMICHI MAEDA ${ }^{3}$, HIROYUKI KITAGAWA ${ }^{1}$ and KAZUHIRO HANAZAKI ${ }^{1}$ \\ ${ }^{1}$ Department of Surgery, ${ }^{2}$ Center for Innovative and Translational Medicine, and \\ ${ }^{3}$ Cancer Treatment Center, Kochi Medical School Hospital, Kochi, Japan
}

\begin{abstract}
Background/Aim: One reason of poor survival rate of patients with pancreatic cancer is the development of chemoresistance. The aim of the present study was to investigate the effects of eribulin mesylate in gemcitabinerefractory advanced pancreatic cancer cell lines. Materials and Methods: Three human pancreatic cancer cell lines (AsPC-1, Panc-1, and SUIT-2) and human pancreatic endoderm ( $h P E)$ cells were used to evaluate the antitumor effects of gemcitabine and eribulin mesylate. Cell viability after treatment of cells with different concentrations of gemcitabine and eribulin mesylate was evaluated using water-soluble tetrazolium salts (WST) assays; cytotoxic effects were evaluated on the basis of morphological changes to cells. Results: Gemcitabine had no effect on cell viability of AsPC-1 nor Panc-1 cells, whereas gemcitabine reduced cell viability of SUIT-2 cells in a dose-dependent manner. Eribulin mesylate significantly reduced cell viability of both AsPC-1 and Panc-1 cells $\quad(p<0.001$ and $p=0.002$, respectively), but had no effect on hPE cells. Microscopic examination of AsPC-1 and Panc-1 cells after treatment with eribulin mesylate revealed morphological changes that included cell shrinkage, membrane blebbing, and fragmentation of the cells after drug exposure, and these were concentration-dependent effects. Conclusion: The findings of the present study suggest that eribulin mesylate may be a promising potential anticancer drug for gemcitabinerefractory advanced pancreatic cancer.
\end{abstract}

This article is freely accessible online.

Correspondence to: Tsutomu Namikawa. Department of Surgery, Kochi Medical School, Kohasu, Oko-cho, Nankoku, Kochi 7838505, Japan. Tel: +81 888802370, Fax: +81 888802371, e-mail: tsutomun@kochi-u.ac.jp

Key Words: Eribulin mesylate, gemcitabine, advanced pancreatic cancer, chemotherapy.
Pancreatic cancer is a commonly diagnosed cancer worldwide, with an extremely poor prognosis, and is the fourth leading cause of cancer-related deaths (1). In patients with recurrent, metastatic, or advanced pancreatic cancer, chemotherapy can prolong survival and improve quality of life compared with best supportive care $(2,3)$. In recent years, gemcitabine, a novel pyrimidine nucleoside analog, has become the standard chemotherapeutic agent used in patients with pancreatic cancer (3). Despite considerable efforts to improve outcomes for these patients, response rates to chemotherapy remain low and the median survival of patients with advanced disease remains in the range of 6 to 10 months $(3,4)$. Therefore, more effective drugs or combination therapies for pancreatic cancer are needed.

Eribulin mesylate, a completely synthetic macrocyclic ketone analog of halichondrin $\mathrm{B}$, which is a natural large polyether macrolide from a rare marine Japanese sponge, acts as a tubulin-binding agent, interfering with microtubule dynamics and suppressing microtubule polymerization without affecting depolymerization $(5,6)$. Although eribulin mesylate is a novel drug that has shown significant activity and efficacy in heavily pretreated patients with refractory breast cancer, its efficacy in the treatment of pancreatic cancer in patients with a poor prognosis is not clear (7). In the present study, we investigated the antiproliferative effects of eribulin mesylate in three different pancreatic cancer cell lines.

\section{Materials and Methods}

Materials and reagents. The present study was performed on three human pancreatic cancer cell lines (AsPC-1, Panc-1, and SUIT-2) and human pancreatic endoderm (hPE) cells. The AsPC-1 and Panc1 cell lines were purchased from the European Collection of Authenticated Cell Cultures (Salisbury, Wiltshire, UK), the SUIT-2 cell line was purchased from the Japan Health Sciences Foundation (Tokyo, Japan), and the hPE cell line was purchased from Cell Systems Corporation (Kirkland, WA, USA). Dulbecco's modified Eagle's medium (DMEM) and antibiotics (penicillin, streptomycin) were purchased from Invitrogen Corporation (New York, NY, USA). Stock solutions of both eribulin mesylate (Halaven powder; Eisai 
Co. Ltd, Tokyo, Japan) and gemcitabine (Gemzar powder; Eli Lilly Co. Ltd, Tokyo, Japan) were created by diluting the drugs in water to a concentration of $0.5 \mu \mathrm{g} / \mu \mathrm{l}$; stock solutions were stored at $-20^{\circ} \mathrm{C}$ until use. Fetal serum albumin (FBS) was obtained from Sigma Chemical (St. Louis, MO, USA).

Cell culture. The three pancreatic cancer cell lines and hPE cells were cultured in DMEM supplemented with penicillin, streptomycin, and $8 \% \mathrm{FBS}$, in a $95 \%$ air $/ 5 \% \mathrm{CO}_{2}$ atmosphere at $37^{\circ} \mathrm{C}$ in a humidified incubator.

Determination of cell viability. The antiproliferative activity of test solutions was determined using water-soluble tetrazolium salts (WST) assays in accordance with the manufacturer's instructions. Briefly, $5 \times 10^{3}$ cells/well were seeded onto 96-well plates and incubated at $37^{\circ} \mathrm{C}$, under $5 \% \mathrm{CO}_{2}$, for $24 \mathrm{~h}$. Different concentrations of gemcitabine $(5,10,50 \mathrm{ng} / \mathrm{ml})$ or eribulin $(0.5,1,5,10 \mathrm{ng} / \mathrm{ml})$ were then added to each well, and cells were incubated for a further $90 \mathrm{~min}$ at $37^{\circ} \mathrm{C}$. The respective concentrations of each drugs used were based on previous in vitro and in vivo studies (5-9). As a control, cells were incubated with saline under the same conditions. At the end of the 90-min incubation period, water-soluble tetrazolium salts (WST) reagent (Sigma-Aldrich, Tokyo, Japan) was added to each well and the cells were incubated for another $90 \mathrm{~min}$ at $37^{\circ} \mathrm{C}$. Absorbance was then measured with a microplate absorbance reader (Molecular Devices, Sunnyvale, CA, USA) using the Cell Counting Kit-8 (Dojindo Molecular Technologies, Rockville, $\mathrm{MD}, \mathrm{USA}$ ) at $450 \mathrm{~nm}$ with a reference wavelength of $620 \mathrm{~nm}$.

Morphological observations. To evaluate morphological changes caused by cytotoxic effects, all cell lines were cultured in a $10-\mathrm{cm}$ dish at a density of $4 \times 10^{5}$ cells $/ \mathrm{ml}$ in a humidified incubator at $37^{\circ} \mathrm{C}$ under $5 \% \mathrm{CO}_{2}$. Gemcitabine $(5,10,50 \mathrm{ng} / \mathrm{ml})$ or eribulin mesylate $(0.5,1,5,10 \mathrm{ng} / \mathrm{ml})$ was added to each dish, and cells were incubated for $24 \mathrm{~h}$ at $37^{\circ} \mathrm{C}$. Cells were then observed under a fluorescence microscope (BZ-9000; Keyence, Itasca, IL, USA) to analyze morphological changes.

Statistical analysis. To determine the significance of differences between two groups under multiple conditions, data were analyzed by one-way analysis of variance, followed by Bonferroni multiple comparison tests. All statistical analyses were performed using PRISM statistical analysis software (GraphPad Software Inc., San Diego, CA, USA). A two-sided $p$-value of less than $<0.05$ was considered significant.

\section{Results}

Effects of gemcitabine on cell viability. The cell viability of the control group was set at $100 \%$ and the effects of gemcitabine on cell viability are expressed relative to the control group (Figure 1). At 5, 10, and $50 \mathrm{ng} / \mathrm{ml}$, gemcitabine significantly reduced the cell viability of SUIT- 2 cells in a dose-dependent manner ( $p<0.001$; Figure 1a). However, although significant dose-dependent effects were seen for 5 , 10 , and $50 \mathrm{ng} / \mathrm{ml}$ gemcitabine on AsPC-1 ( $p=0.005$; Figure 1b) and Panc- 1 cells ( $p=0.046$; Figure $1 \mathrm{c}$ ), the cell viability of these two cell lines did not differ significantly from that of the control group. Thus, these two cell lines are considered gemcitabine-refractory.
In addition, although gemcitabine exhibited significant dose-dependent effects on hPE cells $(p=0.043)$, there was no significant difference in cell viability between control and gemcitabine-treated hPE cells (Figure 1d).

Effects of eribulin mesylate on cell viability. The cell viability of the control group was set at $100 \%$ and the effects of eribulin mesylate on cell viability are expressed relative to the control group (Figure 2). At 0.5, 1, 5, and $10 \mathrm{ng} / \mathrm{ml}$ eribulin mesylate significantly and dose-dependently reduced the cell viability of both AsPC-1 ( $p<0.001$; Figure $2 \mathrm{a})$ and Panc- 1 cells ( $p=0.002$; Figure $2 b)$. Eribulin mesylate had no significant effect on the cell viability of hPE cells at these concentrations (Figure 2c).

Morphological changes. Figure 3 shows representative images of the morphological changes seen following the exposure of AsPC-1 and Panc-1 cells to different concentrations of eribulin mesylate in three independent experiments. Tumor cells from both lines exhibited morphological changes after eribulin mesylate treatment that included cell shrinkage, membrane blebbing, and cell fragmentation. These effects increased with increasing dose of eribulin mesylate. The antiproliferative effects of eribulin mesylate were dose-dependent for both gemcitabine-refractory human pancreatic cancer cell lines.

\section{Discussion}

The results of the present study demonstrated that eribulin mesylate reduces the cell viability of human pancreatic cancer cell lines that are resistant to gemcitabine; these findings were confirmed by morphological analysis and, together, the data indicate inhibition of tumor cell proliferation by eribulin mesylate. To the best of our knowledge, the present study is the first to report on the anticancer effects of eribulin mesylate in gemcitabine-refractory advanced pancreatic cancer cell lines. The findings of the present study suggest that eribulin mesylate has significant potential in the treatment of advanced pancreatic cancer.

Gemcitabine has become the standard treatment for patients with unresectable pancreatic cancer, improving patient survival compared with fluorouracil $(2-4,10)$. However, the prognosis for patients with pancreatic cancer remains poor because of the rapidly progressive and aggressive nature of the disease. Indeed, the median progression-free survival has been reported to be in the range of 2-6 months, or even less in the setting of gemcitabine resistance, despite recent advances in the understanding of the underlying biology of pancreatic cancer and improvements in imaging modalities $(3,4,11)$.

Based on the results of the present study, the pancreatic cancer cell lines could be classified into two groups: gemcitabine-sensitive and -resistant groups. The resistance 

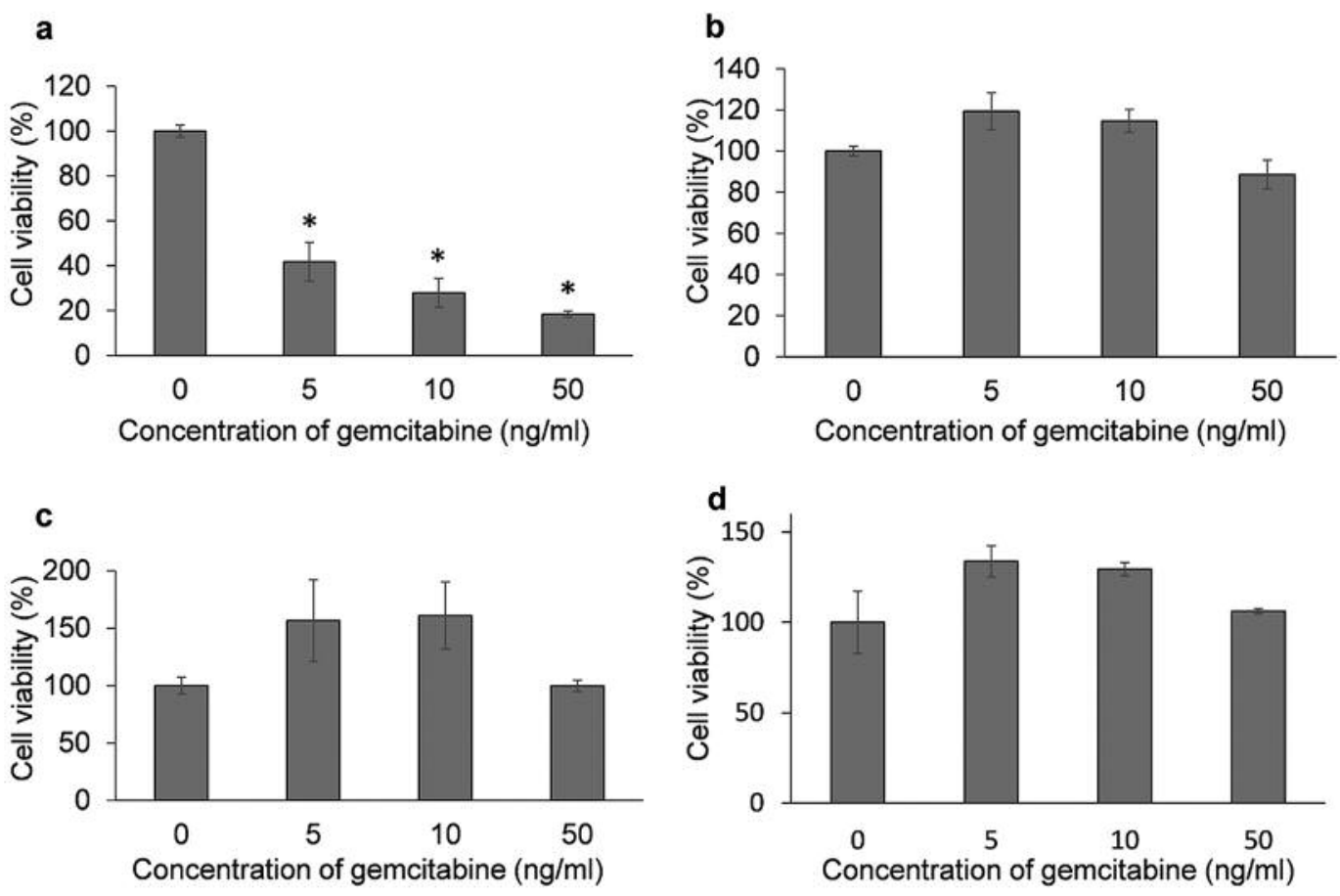

Figure 1. Cell viability in the SUIT-2 (a), AsPC-1 (b), and Panc-1 (c) pancreatic cell lines, as well as of human pancreatic endoderm (hPE) cells (d), with and without gemcitabine treatment, as determined using water-soluble tetrazolium salt assays. Cell viability was set at $100 \%$ in the control group (no drug treatment) and viability after gemcitabine treatment is shown as a percentage of that in the control group. Data are the mean $\pm S D$ of experiments performed in triplicate. *Significantly different from the respective control $(p<0.05)$.
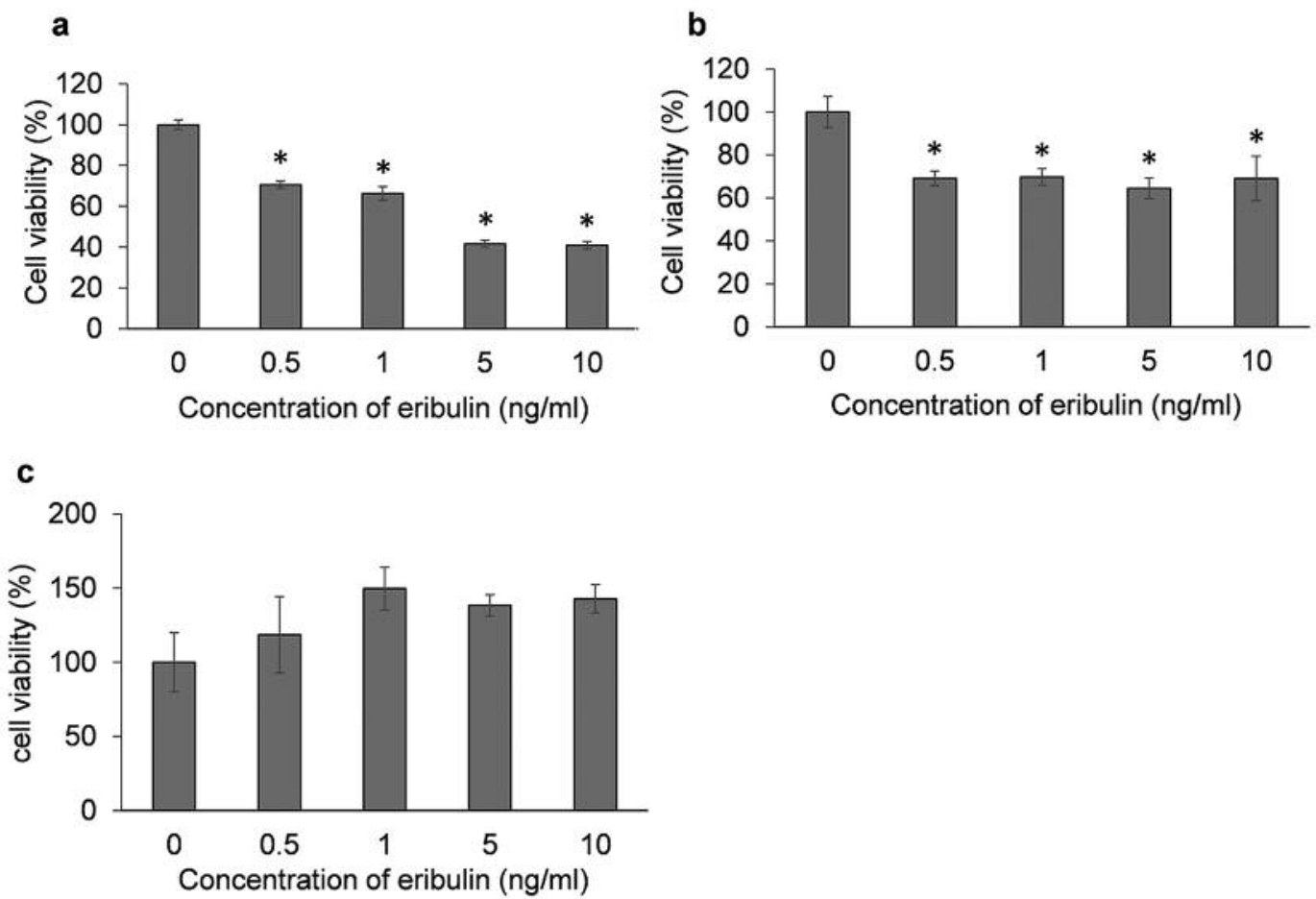

Figure 2. Cell viability in the AsPC-1 (a) and Panc-1 (b) pancreatic cell lines, as well as human pancreatic endoderm (hPE) cells (c), with and without eribulin mesylate treatment, as determined using water-soluble tetrazolium salt assays. Cell viability was set at 100\% in the control group (no drug treatment) and viability after eribulin mesylate treatment is shown as a percentage of that in the control group. Data are the mean $\pm S D$ of experiments performed in triplicate. *Significantly different from the respective control $(p<0.05)$. 

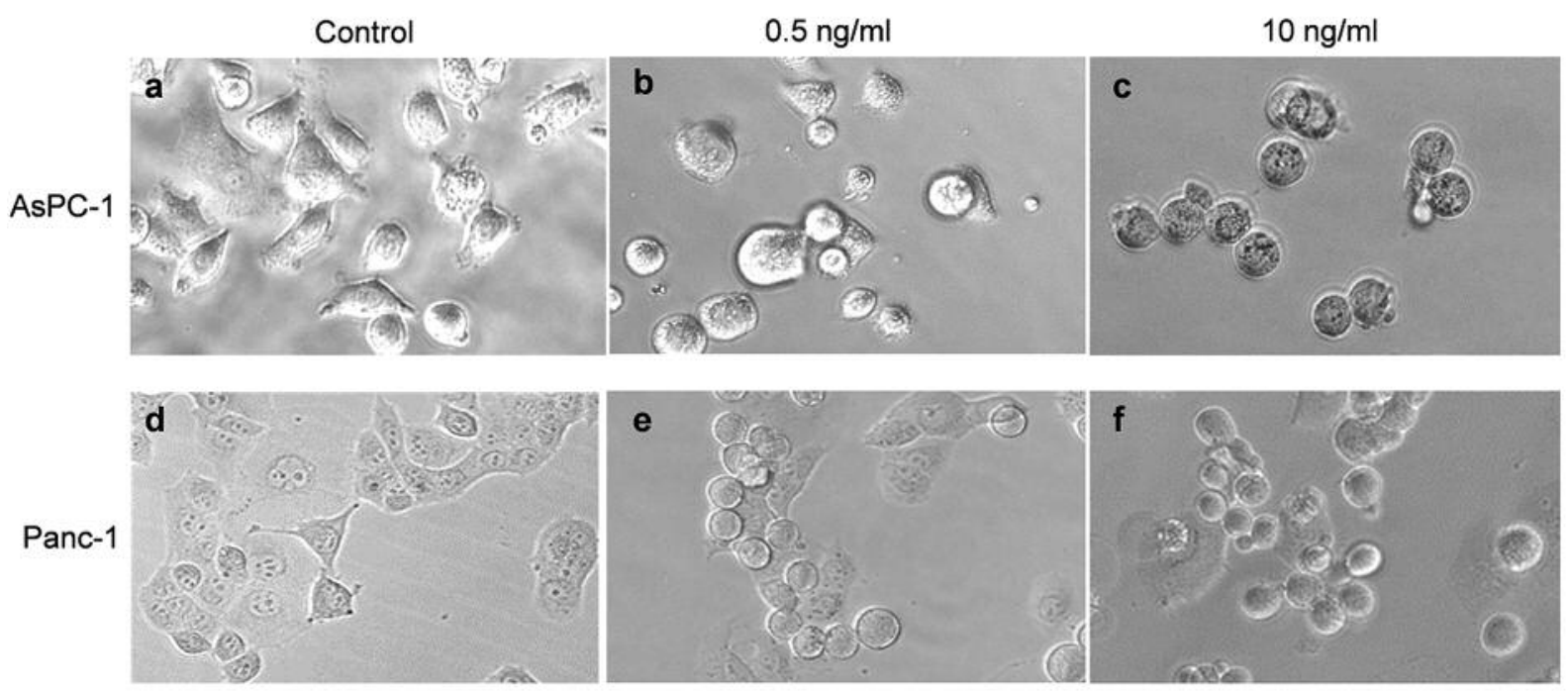

Figure 3. Morphological changes in AsPC-1 and Panc-1 cells, as observed by fluorescence microscopy, after 24 h exposure to 0.5 or 10 ng/ml eribulin mesylate. Control cells were exposed to saline, instead of drug, for $24 \mathrm{~h}$. Morphological changes observed after eribulin mesylate treatment included cell shrinkage, membrane blebbing, and cell fragmentation. The photographs shown are representative images of three independent experiments.

of pancreatic cancer to chemotherapeutic reagents appears to be related to various factors, including nucleoside transport and metabolism, cell-cycle regulation, proliferation, and apoptosis; in addition, multiple gene products are linked to chemoresistance. For example, Akada et al. identified a number of genes that are potentially involved in intrinsic resistance to gemcitabine in pancreatic cancer cell lines, reporting that B-cell lymphoma 2 (BCL2)/adenovirus E1B $19 \mathrm{kDa}$ protein interacting protein and the phosphatidylinositol 3kinase/protein kinase B pathway may play an important role in poor sensitivity to gemcitabine chemotherapy (12). These molecular markers may be promising candidate tools for the detection of gemcitabine chemosensitivity.

Even if patients with pancreatic cancer show initial sensitivity to gemcitabine, development of resistance is common. Therefore, agents that can be used instead of gemcitabine or to overcome gemcitabine resistance are needed $(5,13)$. In Japan, S-1, a combination of tegafur, gimeracil, and oteracil potassium, has been developed as an anticancer drug for the treatment of pancreatic cancer. Various clinical trials using $\mathrm{S}-1$ have demonstrated promising activity not only against gastrointestinal cancer, including gastric cancer and colorectal cancer, but also pancreatic cancer $(4,14,15)$. S-1 monotherapy is accepted as an alternative treatment option for unresectable pancreatic cancer because it is well tolerated and is associated with lower hematological and gastrointestinal toxicities (4). Furthermore, it was expected that the combined administration of $\mathrm{S}-1$ and gemcitabine may be more effective, because the median overall survival for patients with unresectable pancreatic cancer in the gemcitabine, $\mathrm{S}-1$, and combination groups was reported to be 7.5, 8.0, and 10.5 months, respectively (4).

Eribulin mesylate has a unique interaction with tubulin, and this may help overcome the resistance mechanisms that limit the effectiveness of other agents (16). Furthermore, eribulin mesylate may have a role in inactivating BCL2 family proteins, which are mediators of chemoresistance in pancreatic cancer $(7,12)$. Recently, it has been demonstrated that the epithelial-mesenchymal transition (EMT) is a crucial process that is often activated during cancer invasion and metastasis and also induces chemoresistance in cancer treatment $(17,18)$. It has been reported that eribulin mesylate has significant effects on EMT-related pathways, resulting in increased antitumor effects $(19,20)$. The present study clearly shows that eribulin mesylate has antitumor effects, namely reducing cell viability and inducing morphological changes in tumor cells, which could be beneficial in clinical therapy for gemcitabine-refractory advanced pancreatic cancer. Because neither gemcitabine nor eribulin mesylate had any effect on the cell viability of hPE cells, which were derived from human pancreatic endoderm cells, at the concentrations tested, it may be that these concentrations of gemcitabine and eribulin mesylate will prove to be safe for use in humans.

The present study does have some limitations. Firstly, the results reported for the preliminary cytotoxicity tests cannot be extrapolated directly to clinical situations because laboratory studies cannot simulate the complex biological conditions seen in the clinical setting. Recent phase I and II 
clinical studies reported that eribulin mesylate was welltolerated and exhibited anticancer activity in patients with advanced solid tumors $(21,22)$. However, randomized control trials performed on a large number of patients are required to confirm the survival benefit of eribulin mesylate for advanced pancreatic cancer.

In conclusion, the findings of the present study, together with those of previous studies, suggest that eribulin mesylate is a cytotoxic agent that could be developed for use as an anticancer drug for the treatment of gemcitabine-refractory advanced pancreatic cancer. Further studies, including in vivo studies in animal models and clinical randomized control trials, are needed to establish the benefits of and responses to this agent in patients with advanced pancreatic cancer that is resistant to gemcitabine.

\section{Funding}

None.

\section{Conflicts of Interest}

None.

\section{References}

1 Siegel RL, Miller KD and Jemal A: Cancer statistics, 2015. CA Cancer J Clin 65(1): 5-29, 2015.

2 Chauffert B, Mornex F, Bonnetain F, Rougier P, Mariette C, Bouché O, Bosset JF, Aparicio T, Mineur L, Azzedine A, Hammel P, Butel J, Stremsdoerfer N, Maingon P and Bedenne L: Phase III trial comparing intensive induction chemoradiotherapy (60 Gy, infusional 5-FU and intermittent cisplatin) followed by maintenance gemcitabine with gemcitabine alone for locally advanced unresectable pancreatic cancer. Definitive results of the 2000-01 FFCD/SFRO study. Ann Oncol 19(9): 1592-1599, 2008.

3 Huguet F, André T, Hammel P, Artru P, Balosso J, Selle F, Deniaud-Alexandre E, Ruszniewski P, Touboul E, Labianca R, de Gramont A and Louvet C: Impact of chemoradiotherapy after disease control with chemotherapy in locally advanced pancreatic adenocarcinoma in GERCOR phase II and III studies. J Clin Oncol 25(3): 326-331, 2007.

4 Ueno H, Ioka T, Ikeda M, Ohkawa S, Yanagimoto H, Boku N, Fukutomi A, Sugimori K, Baba H, Yamao K, Shimamura T, Sho M, Kitano M, Cheng AL, Mizumoto K, Chen JS, Furuse J, Funakoshi A, Hatori T, Yamaguchi T, Egawa S, Sato A, Ohashi Y, Okusaka T and Tanaka M: Randomized phase III study of gemcitabine plus S-1, S-1 alone, or gemcitabine alone in patients with locally advanced and metastatic pancreatic cancer in Japan and Taiwan: GEST study. J Clin Oncol 31(13): 1640-1648, 2013.

5 Stadel D, Cristofanon S, Abhari BA, Deshayes K, Zobel K, Vucic D, Debatin KM and Fulda S: Requirement of nuclear factor $\mathrm{KB}$ for SMAC mimetic-mediated sensitization of pancreatic carcinoma cells for gemcitabine-induced apoptosis. Neoplasia 13(12): 1162-1170, 2011.
6 Kuznetsov G, Towle MJ, Cheng H, Kawamura T, TenDyke K, Liu D, Kishi Y, Yu MJ and Littlefield BA: Induction of morphological and biochemical apoptosis following prolonged mitotic blockage by halichondrin B macrocyclic ketone analog E7389. Cancer Res 64(16): 5760-5766, 2004.

7 Swami U, Chaudhary I, Ghalib MH and Goel S: Eribulin - a review of preclinical and clinical studies. Crit Rev Oncol Hematol 81(2): 163-184, 2012.

8 Towle MJ, Salvato KA, Budrow J, Wels BF, Kuznetsov G, Aalfs KK, Welsh S, Zheng W, Seletsky BM, Palme MH, Habgood GJ, Singer LA, Dipietro LV, Wang Y, Chen JJ, Quincy DA, Davis A, Yoshimatsu K, Kishi Y, Yu MJ and Littlefield BA: In vitro and in vivo anticancer activities of synthetic macrocyclic ketone analogues of halichondrin B. Cancer Res 61(3): 1013-1021, 2001.

9 Jordan MA, Kamath K, Manna T, Okouneva T, Miller HP, Davis C, Littlefield BA and Wilson L: The primary antimitotic mechanism of action of the synthetic halichondrin E7389 is suppression of microtubule growth. Mol Cancer Ther 4(7): 10861095. 2005.

10 Beger HG, Rau B, Gansauge F, Poch B and Link KH: Treatment of pancreatic cancer: challenge of the facts. World J Surg 27(10): 1075-1084, 2003.

11 Egawa S, Toma H, Ohigashi H, Okusaka T, Nakao A, Hatori T, Maguchi H, Yanagisawa A and Tanaka M: Japan Pancreatic Cancer Registry; 30th year anniversary: Japan Pancreas Society. Pancreas 41(7): 985-92, 2012.

12 Akada M, Crnogorac-Jurcevic T, Lattimore S, Mahon P, Lopes $\mathrm{R}$, Sunamura M, Matsuno $\mathrm{S}$ and Lemoine NR: Intrinsic chemoresistance to gemcitabine is associated with decreased expression of BNIP3 in pancreatic cancer. Clin Cancer Res 11(8): 3094-3101, 2005.

13 Ansari D, Gustafsson A and Andersson R: Update on the management of pancreatic cancer: Surgery is not enough. World J Gastroenterol 21(11): 3157-3165, 2015.

14 Namikawa T, Fukudome I, Ogawa M, Munekage E, Munekage M, Shiga M, Maeda H, Kitagawa H, Kobayashi M and Hanazaki $\mathrm{K}$ : Clinical efficacy of protein-bound polysaccharide $\mathrm{K}$ in patients with gastric cancer undergoing chemotherapy with an oral fluoropyrimidine (S-1). Eur J Surg Oncol 41(6): 795-800, 2015.

15 Koizumi W, Narahara H, Hara T, Takagane A, Akiya T, Takagi M, Miyashita K, Nishizaki T, Kobayashi O, Takiyama W, Toh Y, Nagaie T, Takagi S, Yamamura Y, Yanaoka K, Orita H and Takeuchi M: S-1 plus cisplatin versus S-1 alone for first-line treatment of advanced gastric cancer (SPIRITS trial): a phase III trial. Lancet Oncol 9(3): 215-221, 2008.

16 König J, Hartel M, Nies AT, Martignoni ME, Guo J, Büchler MW, Friess H and Keppler D: Expression and localization of human multidrug-resistance protein $(\mathrm{ABCC})$ family members in pancreatic carcinoma. Int J Cancer 115(3): 359-367, 2005.

17 Mani SA, Guo W, Liao MJ, Eaton EN, Ayyanan A, Zhou AY, Brooks M, Reinhard F, Zhang CC, Shipitsin M, Campbell LL, Polyak K, Brisken C, Yang J and Weinberg RA: The epithelialmesenchymal transition generates cells with properties of stem cells. Cell 133(4): 704-715, 2008.

18 Fischer KR, Durrans A, Lee S, Sheng J, Li F, Wong ST, Choi H, El Rayes T, Ryu S, Troeger J, Schwabe RF, Vahdat LT, Altorki NK, Mittal V and Gao D: Epithelial-to-mesenchymal transition is not required for lung metastasis but contributes to chemoresistance. Nature 527(7579): 472-476, 2015. 
19 Dybdal-Hargreaves NF, Risinger AL and Mooberry SL: Eribulin mesylate: mechanism of action of a unique microtubule-targeting agent. Clin Cancer Res 21(11): 2445-2452, 2015.

20 Yoshida T, Ozawa Y, Kimura T, Sato Y, Kuznetsov G, Xu S, Uesugi M, Agoulnik S, Taylor N, Funahashi Y and Matsui J: Eribulin mesilate suppresses experimental metastasis of breast cancer cells by reversing phenotype from epithelialmesenchymal transition (EMT) to mesenchymal-epithelial transition (MET) states. Br J Cancer 110(6): 1497-1505, 2014.

21 Renouf DJ, Tang PA, Major P, Krzyzanowska MK, Dhesy-Thind B, Goffin JR, Hedley D, Wang L, Doyle L and Moore MJ: A phase II study of the halichondrin B analog eribulin mesylate in gemcitabine-refractory advanced pancreatic cancer. Invest New Drugs 30(3): 1203-1207, 2012.
22 Koczywas M, Frankel PH, Synold TW, Lenz HJ, Mortimer JE, El-Khoueiry AB, Gandara DR, Cristea MC, Chung VM, Lim D, Reckamp KL, Lau DH, Doyle LA, Ruel C, Carroll MI and Newman EM: Phase I study of the halichondrin B analogue eribulin mesylate in combination with cisplatin in advanced solid tumors. Br J Cancer 111(12): 2268-2274, 2014.

Received April 4, 2016

Revised May 24, 2016

Accepted May 25, 2016 